UDC 622.323-057.5:303.622:304.3

\title{
COMPLEX EVALUATION OF HEALTH STATUS AND LIFE QUALITY OF EMPLOYEES OCCUPIED IN MINING AND PROCESSING OF HYDROCARBON RAW MATERIALS
}

\author{
G.G. Gimranova ${ }^{1}$, A.B. Bakirov ${ }^{1}$, L.K. Karimova ${ }^{1}$, Z.F. Gimaeva ${ }^{2}$, N.A. Beigul ${ }^{1}$ \\ ${ }^{1}$ Ufa Research Institute of Occupational Health and Human Ecology, 94 Stepan Kuvykin St., \\ Ufa, 450106, Russian Federation \\ ${ }^{2}$ Bashkir State Medical University, 3 Lenin St., Ufa, 450000, Russian Federation
}

A complex social-hygienic investigation for the assessment of health-related life quality and living standards among 1200 male workers occupied in mining and primary processing of hydrocarbon raw materials has been performed. The study included the method of the anonymous survey for the employee with using a questionnaire developed by WHO experts for the realization of Health, environment and social capital management in enterprises (HESME). The health risk factors' prevalence associated with alcohol, smoking, low physical activity, poor nutrition, stress in the workplace has been established. The feeling of stress and nervousness is generated by the fear of dismissal (18\% of employees), conflicts with administration (4\%) and by financial problems. About 47\% of persons are anxious about social and economic instability. Not more than $4 \%$ of employees consider that the health deterioration is directly related to harmful working conditions. The survey has revealed an inflated self-esteem regarding the health. Thus $59.00 \%$ of employee considers their health status to be excellent or normal, while an objective assessment revealed only $29.7 \%$ of healthy employee. Due to the employee's opinion, the saving of health is conditioned by healthy lifestyle, but the practice of self-preservation behavior is poorly spread. Not more than $37 \%$ of respondents follow the doctors' recommendations. Among the positive process there are changes in dietary habits in everyday life, namely $60 \%$ of the respondents have chosen the balanced diet. The obtained data regarding the quality and way of life of the employee, occupied in mining and processing of hydrocarbon raw materials, should be taken into consideration when developing complex social development programs on an enterprise.

Key words: health status, lifestyle, quality of life, employees occupied in mining and primary processing of hydrocarbon raw materials, harmful production factor, risk factor, psycho-emotional factor, motivation.

World Health Organization (WHO) pays special attention to preservation of laboring population health as only this population group can provide economic and social development of any state [20-23]. In relation to that WHO experts worked out a concept aimed at health management at a workplace and healthy lifestyle formation. Implementation of this concept into practice was called HESME («Health, Environment and Social Capital Management in Enterprises») [17-19].

Over the last ten years of the $20^{\text {th }}$ century and the first 5 years of the $21^{\text {st }}$ century we saw mostly negative trends of primary public health indicators. Many researchers have proved that public health greatly depends on social and economic conditions, lifestyle factors, environment conditions and factors, and medical care level; and lifestyle is considered to be the most important.

It has been proved that smoking, alcohol abuse, irrational nutrition, hypodynamia, and psycho-emotional stress are significant primary health risk factors $[3,4,9]$.

Scientific researches that have been carried out over the last decades mostly cover health problems of workers employed by industrial enterprises $[2,5,6,8,11-15]$. As for life quality and lifestyle of workers dealing with hydrocarbons extraction and processing we did not find a lot of

(C) Gimranova G.G., Bakirov A.B., Karimova L.K., Gimaeva Z.F., Beigul N.A., 2016

Gimranova Galina Ganinovna - Doctor of Medical Science, Deputy Director for Science and organizational and methodical work (e-mail: gala.gim@ mail.ru; tel.: +7 (347) 255-19-03)

Bakirov Akhat Barievich - Doctor of Medical Science, professor, Director (e-mail: fbun@uniimtech.ru; tel. +7 (347) 255-19-57).

Karimova Liliya Kazymovna - Doctor of Medical Science, professor, chief researcher (e-mail: iao_karimova@ rambler.ru; tel.: +7 (347) 255-57-21).

Gimaeva Zulfia Fadievna - Candidate of Medical Science, associate professor of the department of clinical pharmacology and therapy department (e-mail:gzf-33@mail.ru; tel.: +7-927-31-21-197).

Beigul Natalja Aleksandrovna - Candidate of Chemical Sciences, associate professor, chief researcher (e-mail: iao_karimova@rambler.ru; tel.: +7 (347) 255-57-21). 
works on the matter $[1,7]$.

Research goal was to carry out complex assessment of health, life quality, and lifestyle of workers dealing with hydrocarbons extraction and processing.

Data and methods. We carried out a complex social and hygienic research to assess living standard and life quality of 1200 male workers dealing with hydrocarbons extraction and primary processing (drill operators and their assistants, operators, drivers, repairmen, and electricians) with the use of a questionnaire which was designed by WHO experts to allow implementation of European model for health management at a workplace (HESME).

All enterprises covered by our research had social programs for their staff, and all of them implemented practical measures to preserve their workers' health which was the evidence of existing social responsibility. The enterprises also had voluntary medical insurance programs which allowed their workers to receive qualitative medical services and if necessary, sanatoriumresort treatment.

The questionnaire we used included sections concerning social status, lifestyle, labor conditions at a workplace, production and non-production stress factors, health status, physical activity, and nutrition.

Besides we added some questions about workers' financial position and living conditions.

The results of questioning were analyzed with the use of a specially designed program. As for respondents' age most of them belonged to 41-60 age group and their professional experience was 15-20 years.

Results. The research results enabled us to fully assess workers' health status, life quality, and lifestyle, including prevalence of such significant primary health risk factors as smoking, alcohol drinking, irrational nutrition, hypodynamia, and psycho-emotional stress.

The great majority of workers (85\%) employed by the enterprises we researched lived in separate apartments; $15 \%$ had rooms in shared flats or dormitories with conveniences. Housing provision of majority of workers was quite sufficient; $60 \%$ of respondents had 9 or more square meters per one family member, $35 \%$ had 5.7 square meters and only $5 \%$ had less than 5 square meters per one family member.

As for marital status, $74 \%$ men were married, $9 \%$ were living in an unregistered marriage, $8 \%$ were divorced and $9 \%$ had never been married.
Most families (51\%) consisted of 4 members (a husband and a wife and two children). Families with many children accounted for $8 \%$.

Respondents' wages differed from 35 to 75 thousand rubles which was higher than average Russian level of 32 thousand rubles (according to Federal Statistic Service).

Most workers $(80 \%)$ were quite satisfied with their family relations; $9 \%$ considered their family relations unsatisfying, and $11 \%$ found that question difficult to answer.

Respondents were mostly qualified workers with specialized secondary education $(45 \%)$ and high education (30\%).

The life and labor satisfaction levels are considered to be the most important integral indicators of workers' mental and social wellbeing. Only 5\% workers estimated their living standard as high; 54\% thought it was average, and $41 \%$ stated it was below average.

Labor peculiarities, labor conditions and labor content for workers dealing with hydrocarbons extraction and processing are associated with adverse effects of a full set of harmful production factors. When assessing labor conditions and making a list of most harmful and dangerous production factors $50 \%$ respondents mentioned increased labor intensity; 25\% named unfavorable micro-climate (too high or low temperatures when working outdoors); $18 \%$ were preoccupied with adverse chemicals' content in working area air; $12 \%$ mentioned flammability and explosibility of production; 9\% worried about being responsible for other people's safety; $8 \%$ were afraid of traumatism; and $7 \%$ mentioned risks related to business trips and removals.

Hygienic researches proved that the most significant harmful production factors of working environment and labor process in hydrocarbons extraction and processing were noise, vibration, and athletic overexertion. But still, few workers estimated them as unfavorable; $12 \%$ complained about production noise, $4 \%$ about vibration, and $8 \%$ mentioned hard physical labor. $21 \%$ respondents considered their working conditions to be quite safe.

Most workers $(76 \%)$ were satisfied with their working conditions, while $15 \%$ called them unsatisfactory. $9 \%$ respondents found the question difficult to answer.

We detected the following prevalence of primary health risk factors among workers. First of all, one third of them smoked; $28 \%$ respondents smoked up to one pack of cigarettes a day, $3 \%$ up 
to two or even more, and $4 \%$ suffered from passive smoking.

$6 \%$ respondents admitted drinking once a week; $10 \%$ drank twice a month, and $40 \%$ respondents claimed they drank only on special occasions. We should note that when answering such questions respondents were not completely honest; we can understand the reasons for that dishonesty but we have to estimate the figures as being somewhat understated.

We all know the fact that psycho-emotional factors are among the most significant ones exerting negative influence on a person's health. These factors can cause various psychosomatic diseases such as neurotic disorders, circulatory system diseases, pancreatic diabetes, stomach and duodenum ulcer, and certain malignant diseases $[10,16]$.

According to workers' questioning the leading rank place in the structure of psychosocial factors of production genesis belonged to factors of increased labor intensity (the answers were "too stressful work", $6 \%$; irregular working hours", $5 \%$; "too great responsibility", $8 \%$, "too many changes at a workplace", $10 \%$ ).

$4 \%$ workers complained about conflicts with supervisors and unjust treatment. $18 \%$ worried about a possibility of dismissal. 33\% workers reported they had no stress at their workplace.

According to questioning financial problems caused the biggest share of nervousness or stress in workers' families. $15 \%$ workers were preoccupied with insufficiency of their financial resources, $7 \%$ were afraid of unforeseen substantial expenses, $17 \%$ worried about their children's future, and $4 \%$ were concerned about difficulties related to their children's study at higher educational establishments. $18 \%$ were anxious about crisis in the country's economy and social instability. $7 \%$ worried about a possible disease of a family member; $6 \%$ were afraid of a death of a family member. 5\% workers had a stress related to interpersonal family conflicts and quarrels with other people.

Thus, we can name such production and nonproduction factors as increased labor intensity, fear of being dismissed, financial problems, worries about children's future, and social instability, as the most significant reasons that can cause stress for workers dealing with hydrocarbons extraction and processing.

$26 \%$ respondents claimed that solution to their financial problems, pay rise in particular, would decrease anxiety and uneasiness. 29\% workers saw improvements of their relations with relatives as a way to preserve their health. 15\% respondents tried to learn to control their emotions. About 25\% workers thought that career development would help them to decrease anxiety.

Though we didn't detect any people who reported alcohol abuse when answering the questions in the section connected with drinking, we can still see that about $5 \%$ respondents considered drinking alcohol a way to reduce stress. $13 \%$ respondents didn't know what to do in such a situation.

About $28 \%$ workers thought ageing to be the main reason for health deterioration, $14 \%$ named unfavorable ecological situation, $6 \%$ put unsettled life on the first place and $4 \%$ thought it was harmful labor conditions.

According to workers' questioning 35\% put their children future on the first place among their greatest fears about the nearest future, and $24 \%$ gave unemployment the first rank. $19 \%$ pointed out the importance of their health preservation and $18 \%$ were preoccupied with the family members' health (picture 1). 


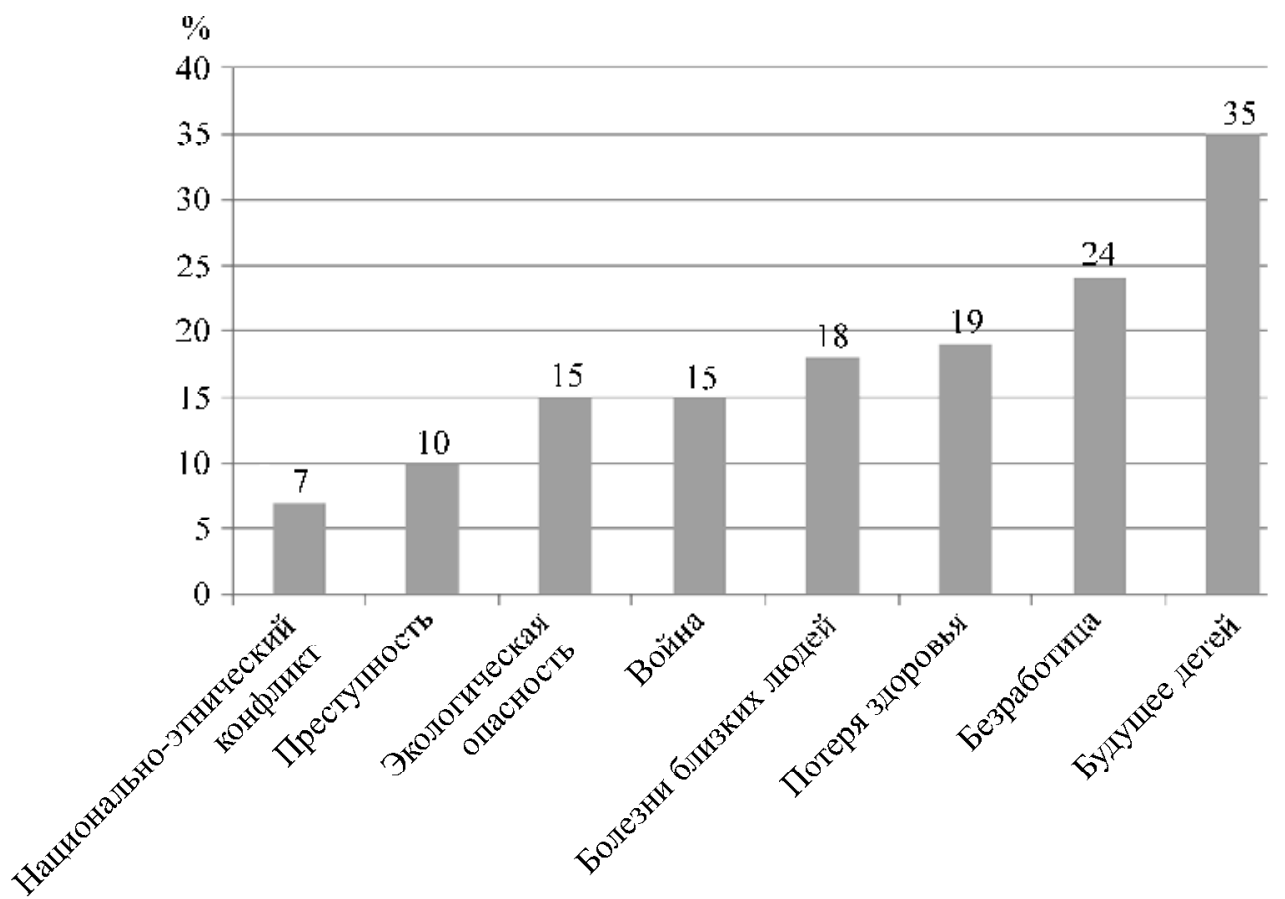

Picture 1 - Greatest fears about nearest future for workers dealing with hydrocarbons extraction and processing From left to right: national and ethnic conflicts, criminality, ecological dangers, war, diseases of family members, loss of health, unemployment, children's future

About half of respondents (14\%) worried about social and ecologic instability in the country. $15 \%$ spoke about possible ecological dangers, $15 \%$ mentioned threat of war, $10 \%$ worried about increase in criminality and violence, and criminogenic situation deterioration, $7 \%$ were afraid of national and ethnic conflicts.

$15 \%$ workers considered ecologic situation in their place of living as unfavorable, $41 \%$ found the question difficult to answer. 28\% thought the ecological situation was quite normal. 59\% considered poor quality of drinking water and foodstuffs to be the acutest ecological problems, and $22 \%$ put air pollution and gas contamination of atmosphere on the first place.

As balance and safety of foodstuffs is one of the most important factors providing for health preservation we included questions concerning nutrition in our research. According to workers' questioning, most respondents (49\%) considered their nutrition satisfactory; $40 \%$ called it quite good, $7 \%$ thought it was excellent and only $4 \%$ complained about bad nutrition. A big share of respondents $(41 \%)$ saw increase of fish products, vegetables and fruit in their ration as a way to improve nutrition; $27 \%$ thought they should eat more ecologically clean foodstuffs. $24 \%$ considered drinking purified water to be very important for their health improvement, and $14 \%$ stated they should eat less fat foodstuffs.

As questioning showed $60 \%$ workers dealing with hydrocarbons extraction and processing changed their nutrition habits over the last years. $41 \%$ started to eat more fruit and vegetables, 34\% more fish and seafood, $23 \%$ vegetable fats, $21 \%$ started to eat more dairy products. $30 \%$ reduced consumption of sugar, $13 \%$ started to eat less animal fats. 37\% respondents stated that the main reason for those changes was their desire to pursue healthy lifestyle, and $11 \%$ respondents wanted to lose some weight.

$15 \%$ workers had active physical activity (work on training devices, aerobics, swimming, and cycling) once a week; $16 \%$ workers did it 3 or 5 times a week and $27 \%$ respondents said they did no sports.

According to questioning results we obtained information on how workers estimated their health. $12 \%$ oil industry workers thought their health was excellent, $47 \%$ considered it good and $41 \%$ said it was quite satisfactory. Mostly young workers claimed to have excellent health. We should note that there were no workers estimating their health as poor and very poor.

The most frequent complaints about health included periodical toothaches and gingival hemorrhage $(15 \%)$, pains in joints $(13 \%)$, pyrosis 
$(11 \%)$, headaches $(10 \%)$, and pains in heart $(7 \%)$. $20 \%$ of smokers mentioned coughing in the morning. $15 \%$ respondents had age-dependant sight deterioration.

$28 \%$ workers admitted having gastrointestinal tract diseases in their case history, $14 \%$ had spinal column diseases, $8 \%$ suffered from respiratory diseases and 6\% had joint diseases. Only 5\% workers complained about having acute conditions of chronic diseases during the year.

More than one third of respondents (32\%) suffered from catarrhal diseases over the last 12 months. 3\% respondents had industrial injuries, including those incurred on the way to work.

We should point out that only $7 \%$ respondents were aware of their arterial hypertension; 50\% workers stated that their systolic blood pressure was about 120-139 mm of mercury column, and diastolic blood pressure was 90-94 mm of mercury column. 5\% respondents had systolic blood pressure at $140-159 \mathrm{~mm}$ of mercury column and diastolic pressure at 90-94. 28\% respondents didn't know their blood pressure parameters.

More than a half of workers $(55 \%)$ visited a polyclinic not more than once a year and $12 \%$ did it twice or three times a year. Respondents visited therapists most frequently (33\%), then common profile surgeons (7\%) and neurologists (4\%). About 52\% workers didn't have any sickness certificates during the year or they had only one sick list (acute respiratory virus infections or catarrhal diseases were the most frequent reasons). $16 \%$ respondents didn't go to a polyclinic in case of health problems.

$37 \%$ workers followed doctors' prescriptions after a visit to a polyclinic. $35 \%$ workers took medicines; $10 \%$ took anti-inflammatory drugs, $8 \%$ took analgesics, $7 \%$ took antibiotics and $5 \%$ took gastrointestinal medicines. 9\% respondents took cardio-vascular medicines including hypotensive drugs. Workers mostly preferred to take medicinal herbs $(21 \%)$ and vitamins (19\%). More than one third of respondents (32\%) took drugs without doctors' prescriptions. Medicines were bought with the use of official prescriptions only in $9 \%$ of cases.

According to the results of periodical medical examinations comprising 7,500 workers dealing with hydrocarbons extraction and processing it was detected that only $29.7 \%$ of all examined workers could be considered practically healthy. $70.3 \%$ workers had chronic pathologies. As for diagnosed diseases the first place among them belongs to locomotor apparatus pathologies and peripheral nervous system pathologies (33.5\%); arterial hypertension accounted for $29.2 \%$, ENT-organs diseases took the third place $(17.7 \%$; among them sensorineural hearing loss $5.7 \%$, otitis $5.9 \%$, chronic diseases of upper air passages $6.1 \%$ ); gastrointestinal chronic diseases accounted for $11.3 \%$

$21 \%$ worker thought they should pay more attention to their health. To improve their health $20 \%$ workers wanted to give up smoking, $18 \%$ wished to have sanatorium treatment, $16 \%$ decided to do physical training and $12 \%$ wanted to get rid of main reasons for anxiety (table 1).

Table 1

Basic measures aimed at health improvement stated by workers dealing with hydrocarbons extraction and processing (as per questioning results)

\begin{tabular}{|l|c|}
\hline \multicolumn{1}{|c|}{ Answer options from questionnaires } & $\begin{array}{c}\text { Quantity of } \\
\text { respondents, } \%\end{array}$ \\
\hline To be more physically active & 29 \\
\hline To drink pure water & 23 \\
\hline To think about one's health more & 21 \\
\hline To eat ecologically clean foodstuffs & 20 \\
\hline To give up smoking & 20 \\
\hline To have treatment in a sanatorium & 18 \\
\hline To have better nutrition & 18 \\
\hline To do sports regularly & 16 \\
\hline To get rid of main reasons for anxiety & 12 \\
\hline To master time-management & 11 \\
\hline To master self-control & 7 \\
\hline To drink less alcohol & 5 \\
\hline
\end{tabular}

Thus, most workers dealing with hydrocarbons extraction and processing considered healthy lifestyle to be the most important factor of health preservation. Workers admitted having personal responsibility for their own health as well as health of their family members.

The data we obtained on life quality, social profile, medical and social peculiarities of lifestyle, and workers' health status can be used for designing complex programs aimed at workers' health protection and improvement.

\section{Conclusions.}

Prevalence of health risk factors associated with lifestyle is characterized by systematic drinking (twice a month or more, 60\% respondents), active smoking (one third of respondents), low physical activity (27\% workers reported having no physical activity), and stress at workplace. However we didn't detect any cases of alcohol abuse.

Not more than $4 \%$ workers considered their health deterioration was caused by harmful labor conditions. 
Generally respondents tended to overestimate their health; 59\% respondents thought their health was excellent while our objective estimation showed that only $29.7 \%$ workers could be considered practically healthy. To preserve their health most workers thought it necessary to pursue healthy lifestyle. But at the same time selfpreservation behavior was not very widely spread.

When enterprises work out complex programs of their social development we recommend them to take information on life quality and lifestyle of workers dealing with hydrocarbons extraction and processing into account.

\section{Reference}

1. Ashurova M.D., Azimov M.K., Hoshimov A.E. Vlijanie obraza zhizni i promyshlenno-proizvodstvennyh faktorov na sostojanie zdorov'ja rabotajushhih [Influence of the lifestyle and industrial production factors on employees' halth status]. Aktual'nye voprosy sovremennoj mediciny: materialy sbornika nauchnyh trudov po itogam mezhvuzovskoj ezhegodnoj zaochnoj nauchno-prakticheskoj konferencii s mezhdunarodnym uchastiem, Yekaterinburg, 2014, pp. 62-64. (in Russian).

2. Bakirov A.B., Simonova N.I. Regional'nye aspekty konceptual'noj modeli upravlenija zdorov'em, ohranoj truda i okruzhajushhej sredoj na predprijatijah neftedobychi, neftehimii i mashinostroenija $\mathrm{v}$ uslovijah Respubliki Bashkortostan [Regional aspects of the conceptual model for health management, protection of labor and production environment on oil companies, petrochemical and mechanical engineering in the Republic of Bashkortostan]. Materialy pervoj mezhdunarodnoj konferencii seti Vsemirnoj organizacii zdravoohranenija stran Vostochnoj Evropy po problemam kompleksnogo upravlenija zdorov'em rabotajushhih, 21-25 Sept., Ufa, 2003, pp. 70-78.

(in Russian).

3. Belova E.A. Vlijanie obraza zhizni i social'nyh faktorov na uroven' zdorov'ja cheloveka [The way of life and social factors and their influence on the level of human's health]. Uchenye zametki TOGU, 2013, vol. 4, no. 4, pp. 687-693. (in Russian).

4. Kosolapov L.I., Letnikova G.V. [et al.] Vlijanie social'no-jekonomicheskih faktorov i obraza zhizni na zdorov'e naselenija $v$ Voronezhskoj oblasti [The impact of socio-economic factors and lifestyle on the health of the population in the voronezh region]. Sistemnyj analiz $i$ upravlenie v biomedicinskih sistemah, 2015, vol.14, no. 4, pp. 820-828. (in Russian).

5. Egorova A.G., Kikou P.F., Gorboroukova T.V. Social'no-gigienicheskie aspekty vlijanija obraza zhizni na uroven' rasprostranennosti boleznej sistemy krovoobrashhenija u naselenija trudosposobnogo vozrasta Respubliki Saha (Jakutija) [Social-hygienic aspects of influence of the lifestyle on prevalence level of blood circulation system diseases in able-bodied population of Sakha Republic (Yakutia)]. Obshhestvennoe zdorov'e i zdravoohranenie, 2010, no. 2, pp. 24-27. (in Russian).

6. Kouzmin S.V., Khasanova G.N., Oransky I.E., Roslaya N.A. Kachestvo zhizni u rabochih kriolitovogo proizvodstva $\mathrm{v}$ zavisimosti ot trudovogo stazha [Life quality in cryolite production workers, in accordance with length of service]. Medicina truda i promyshlennaja jekologija, 2012, no. 6, pp. 14-17. (in Russian).

7. Kislitsyna V.V. Ocenka vlijanija social'no-bytovyh faktorov i obraza zhizni na sostojanie zdorov'ja rabotnikov promyshlennogo predprijatija [Evaluation of the impact of social and household factors and lifestyle on the workers' health at the industrial enterprise Modern scientific research and innovation]. Sovremennye nauchnye issledovanija i innovacii, 2013, no. 9, pp. 35. (in Russian).

8. Koudrina E.A., Artemyeva N.N. Social'no-gigienicheskaja harakteristika uslovij truda, zdorov'ja i kachestva zhizni specialistov so srednim medicinskim obrazovaniem, rabotajushhih $\mathrm{v}$ sisteme skoroj medicinskoj pomoshhi [Socio-hygienic characteristics of working conditions, health and quality of life of specialists with secondary medical education, working in the emergency system]. Obshhestvennoe zdorov'e i zdravoohranenie, 2010, no. 4, pp. 31-36. (in Russian).

9. Ovsyannikova M.A. Zdorovyj obraz zhizni naselenija Smolenskogo regiona i faktory, na nego vlijajushhie [Healthy lifestyle of the population in Smolensk region and the factors influencing it]. Social'no-jekonomicheskoe razvitie organizacij regionov Belarusi: Jeffektivnost' $i$ innovacii: materialy dokladov mezhdunar. nauch.-prakt. konf. Vitebsk, 28-29 Okt. 2015 g, Vitebsk, 2015, pp. 244-246. (in Russian).

10. Oganov R.G., Shal'nova S.A., Kalinina A.M. Profilaktika serdechno-sosudistyh zabolevanij: rukovodstvo [Prevention of cardiovascular diseases: a Guide]. Moscow: GJeOTAR-Media, 2009, 216 p. (in Russian).

11. Odintseva O.V., Semenikhin V.A, Mendiakova E.V. Kachestvo zhizni rabotnikov ugledobyvajushhih predprijatij Kuzbassa [Life quality of workers engaged into coal-extracting enterprises of Kouzbass]. Medicina truda i promyshlennaja jekologija, 2011, no. 12, pp. 29-32. (in Russian.

12. Bakirov A.B., Nafikov R.G., Ibatullina R.B., Simonova N.I. Osobennosti professional'nogo stressa v uslovijah proizvodstva: klinicheskie i jeksperimental'nye aspekty: nauchnyj obzor [Characteristics of occupational 
stress in the production environment: Clinical and experimental aspects: Scientific review]. FGU Ufimskij NII mediciny truda i jekologii cheloveka Minzdravsocrazvitija Rossii, Ufa, 2005, 40 p. (in Russian).

13. Pomytkina, T.E. Ocenka kachestva zhizni bl'nyh jazvennoj bolezn'ju, rabotajushhih na krupnom himicheskom predprijatii Zapadnoj Sibiri, v zavisimosti ot srokov i variantov lechenija [Assessment of quality of life in workers with ulcer disease at a large chemical plant in West Siberia in relation to treatment periods and options] Zdravoohranenie Rossijskoj Federacii, 2011, no. 1, pp. 40-43. (in Russian).

14. Solomaj T.V. Ocenka faktorov, vlijajushhih na zdorov'e s tochki zrenija sistemy upravlenija riskami [Assessment of the factors influencing health in terms of the risk management system]. Sanitarnyj vrach, 2012 , no. 10, pp. 69-74. (in Russian).

15. Dekhnich S.N., Ugnenko N.M., Filimonova O.L., Peregontseva N.V., Morozova A.S., Berks P.M. Sravnitel'naja harakteristika kachestva zhizni vrachej centrov zdorov'ja i rukovoditelej lechebno-profilakticheskih uchrezhdenij [Comparative characteristics of the quality of life of physicians of health centers and heads of medical institutions]. Kazanskij medicinskij zhurnal, 2011, no. 4, pp. 593-597. (in Russian).

16. Belki K.L., Landsbergis P.A., Schnall P.l., Baker D. Is job strain a major source of cardiovascular disease risk? A critical review of the empirical evidence, with a clinical perspective. Scandinavian Journalof Work, Environment\&Health, 2004, vol.30, no. 2, pp. 85-128.

17. Lehtinen $\mathrm{S}$. Challenges to occupational health services in the Regions. The national and international responses. Proceedings of a WHO/ICOH/ILO. Finish institute of occupational health, Helsinki, 2005, pp. 16-19.

18. Paoli P., Parent-Thirion A. Working conditions in the acceding and candidate countries. European Foundation for the Improvement of Living and Working Conditions, Geneva, 2003, 122 p.

19. Rantanen J. Basic Occupational Health Services. Helsinki, 2005, 19 p.

20. Renewing primary health care in the Americas: a position paper of the Pan American Health Organization, 2007, 48 p.

21. Saltman R., Rico A., Boerma W. Primary health care in the driver's seat: organizational reform in European primary care. Maidenhead, England, Open University Press, 2006 (European Observatory on Health Systems and Policies Series). 286 p.

22. Report on the review of primary care in the African Region. Brazzaville, World Health Organization Regional Office for Africa, 2003, 97 p.

23. Integrated community-based interventions: 2007 progress report to STAC(30). Geneva, United Nations Development Programme/World Bank/ World Health Organization Special Programme for Research and Training in Tropical Diseases, 2008 (TDR Business Line 11), 38 p

Gimranova G.G., Bakirov A.B., Karimova L.K., Gimaeva Z.F., Beigul N.A. Complex evaluation of health status and life quality of employees occupied in mining and processing of hydrocarbon raw materials. Health Risk Analysis, 2016, no. 2, pp. 36-44. 